\title{
Strategi Peningkatan Kualitas Pelayanan Berbasis SWOT pada Online Store Shopee
}

\author{
Mutiara Lusiana Annisa \\ Politeknik PalComTech \\ mutiara_annisa@palcomtech.ac.id
}

Abstrak
kujuan dari penelitian ini adalah agar dapat menganalisis bagaimana
kekuatan, kelemahan, peluang dan ancaman dari penggunaan online
store shopee. Penelitian yang dilakukan bersifat kualitatif. Adapun
pengambilan data menggunakan penyebaran kuesioner. Sedangkan
untuk teknik pengolahan data yang digunakan adalah dengan
menggunakan metode SWOT. Penentuan populasi melibatkan pihak
internal dan pihak eksternal. Teknik yang digunakan adalah dengan
menggunakan metode SWOT. Dimana pihak internal melibatkan
admin seller yang mempunyai akses secara langsung kepada
konsumen sedangkan pihak eksternal yaitu mahasiswa yang berada
dikawasan kota Palembang. Adapun hasil penelitian menunjukkan
bahwa dari sisi internal berada pada koordinat 0.54, sedangkan dalam
matrik faktor sedangkan pada sisi eksternal berada pada koordinat
0.37. Sehingga dari pemetaan matrik internal dan matrik eksternal
menunjukkan bahwa Shopee masih berada pada posisi kuat dan masih
memiliki peluang bisnis.
Kekuatan, Kelemahan, Peluang, Ancaman, Kualitas Pelayanan,
Shopee

\section{PENDAHULUAN}

Shopee merupakan salah satu marketplace terbesar yang menduduki posisi ke lima terbesar di Indonesia. Shopee berada dibawah naungan Garena (berubah nama menjadi SEA Group) yaitu perusahaan Internet di Asia Tenggara. Dengan Menjalankan model bisnis C2C (customer to customer) mobile marketplace dan mall online yang diusung Shopee, memungkinkan kehadirannya dapat dengan mudah diterima oleh berbagai lapisan masyarakat, termasuk di Indonesia. Shopee akhirnya resmi diperkenalkan di Singapura pada tahun 2015 kemudian diikuti oleh negara Malaysia, Filipina, Taiwan, Thailand, Vietnam, dan Indonesia.

Adapun visi pada Shopee adalah "Menjadi C2C Mobile Marketplace Nomor 1 di Asia Tenggara", Shopee yang berada di bawah naungan CEO, Chris Feng, pria lulusan terbaik dari Universitas Nasional Singapura yang memungkinkan para penggunanya membeli atau menjual barang melalui aplikasi yang tersedia di platform iOS dan Android.

Shopee Indonesia resmi diperkenalkan di Indonesia pada Desember 2015 di bawah naungan PT Shopee International Indonesia. Sejak peluncurannya, Shopee Indonesia mengalami perkembangan yang sangat pesat, bahkan hingga Oktober 2017 aplikasinya sudah diunduh oleh lebih dari 25 juta pengguna. Menawarkan one stop mobile experience, Shopee menyediakan fitur live chat yang memudahkan para penjual dan pembeli untuk saling berinteraksi dengan mudah dan cepat. Shopee Indonesia sebagai sarana jual beli daring yang 
menyediakan berbagai produk untuk menunjang aktivitas sehari-hari yang mencakup fashion, gadget, alat kosmetik, alat elektronik, hobi dan koleksi, fotografi, perlengkapan olahraga, otomotif, vitamin dan suplemen, perlengkapan rumah, makanan dan minuman, souvenir dan pesta, hingga voucher belanja.

Shopee didalam mencapai visi dan misi memerlukan adanya strategi-strategi untuk meningkatkan kualitas pelayanan. Kualitas pelayanan dapat diketahui dengan melihat faktor internal dan faktor eksternal melalui suatu analisis yaitu analisis SWOT. Analisis SWOT dapat membantu didalam menentukan kekuatan, kelemahan, ancaman, dan peluang pada suatu perusahaan atau organisasi. Dengan melakukan analisis SWOT maka diharapkan bisa membantu mewujudkan visi dan misi pada Shopee serta dapat membantu di dalam penyusunan suatu rencana yang matang untuk mencapai tujuan yaitu memaksimalkan penerimaan pendapatan pada Shopee. Oleh karena itu, penelitian ini diperlukan untuk menganalisis kekuatan, kelemahan, peluang dan ancaman pada kualitas pelayanan yang diberikan Shopee kepada konsumen.

\section{LANDASAN TEORI}

Kualitas merupakan suatu kondisi dinamis yang berpengaruh dengan produk, jasa, manusia, proses dan lingkungan yang memenuhi atau melebihi harapan (Tjiptono, 2001). Sehingga definisi kualitas pelayanan dapat diartikan sebagai upaya pemenuhan kebutuhan dan keinginan konsumen serta ketepatan penyampaiannya dalam mengimbangi harapan konsumen (Tjiptono, 2007). Kualitas pelayanan (service quality) dapat diketahui dengan cara membandingkan persepsi para konsumen atas pelayanan yang nyata-nyata mereka terima / peroleh dengan pelayanan yang sesungguhnya mereka harapkan / inginkan terhadap atributatribut pelayanan suatu perusahaan. Jika jasa yang diterima atau dirasakan (perceived service) sesuai dengan yang diharapkan, maka kualitas pelayanan dipersepsikan baik dan memuaskan, jika jasa yang diterima melampaui harapan konsumen, maka kualitas pelayanan dipersepsikan sangat baik dan berkualitas.Sebaliknya jika jasa yang diterima lebih rendah daripada yang diharapkan, maka kualitas pelayanan dipersepsikan buruk. Enam prinsip kualitas pelayanan menurut Wolkins yang dikutip oleh (Saleh, 2010) meliputi kepemimpinan, pendidikan, perencanaan, review, komunikasi, penghargaan dan pengakuan.

Menurut Kotler (2002:83) definisi pelayanan adalah setiap tindakan atau kegiatan yang dapat ditawarkan oleh suatu pihak kepada pihak lain, yang pada dasarnya tidak berwujud dan tidak mengakibatkan kepemilikan apapun. Produksinya dapat dikaitkan atau tidak dikaitkan pada satu produk fisik. Pelayanan merupakan perilaku produsen dalam rangka memenuhi kebutuhan dan keinginan konsumen demi tercapainya kepuasan pada konsumen itu sendiri. Kotler juga mengatakan bahwa perilaku tersebut dapat terjadi pada saat, sebelum dan sesudah terjadinya transaksi. Pada umumnya pelayanan yang bertaraf tinggi akan menghasilkan kepuasan yang tinggi serta pembelian ulang yang lebih sering. Kata kualitas mengandung banyak definisi dan makna, orang yang berbeda akan mengartikannya secara berlainan tetapi dari beberapa definisi yang dapat kita jumpai memiliki beberapa kesamaan walaupun hanya cara penyampaiannya saja biasanya terdapat pada elemen sebagai berikut:

1. Kualitas meliputi usaha memenuhi atau melebihkan harapan pelanggan.

2. Kualitas mencakup produk, jasa, manusia, proses dan lingkungan

3. Kualitas merupakan kondisi yang selalu berubah.

Belanja online (online shopping) adalah proses dimana konsumen secara langsung membeli barang-barang, jasa dan lain-lain dari seorang penjual secara interaktif dan real-time 
tanpa suatu media perantara melalui Internet (Mujiyana \& Elissa, 2013).Online shopping atau belanja online via internet, adalah suatu proses pembelian barang atau jasa dari mereka yang menjual melalui internet, atau layanan jual-beli secara online tanpa harus bertatap muka dengan penjual atau pihak pembeli secara langsung (Sari, 2015). Jadi, belanja online adalah proses jual-beli barang, jasa dan lain-lain yang dilakukan secara online tanpa bertemu dahulu antara penjual dan pembeli.

Analisis SWOT adalah identifikasi berbagai faktor secara sistematis untuk merumuskan suatu strategi. Analisis ini didasarkan pada logika yang dapat memaksimalkan kekuatan dan peluang, namun bersamaan dapat meminimalkan kelemahan dan ancaman (rangkuti, 2009). Untuk mengetahui posisi perusahaan digunakan suatu alat pendekatan yaitu analisis SWOT (Strenght, Weakness, Opportunity, dan Threat). Kekuatan (Strenght) dan kelemahan (Weakness) dapat diketahui dengan melakukan analisis faktor internal, sedangkan kesempatan (Opportunity) dan ancaman (Threat) dapat diketahui melalui faktor eksternal.

Berikut pengertian Strengths, Weaknesses, Opportunities, Threats menurut Pearce dan Robinson (2011) :

a. Strengths (Kekuatan) merupakan sumberdaya yang dikendalikan oleh atau tersedia bagi perusahaan yang membuat perusahaan relative lebih unggul dibandingkan dengan pesaingnya dalam memenuhi kebutuhan pelanggan yang dilayaninya.

b. Weaknesses (Kelemahan) merupakan keterbatasan atau kekurangan dalam satu atau lebih sumber daya suatu perusahaan terhadap pesaingnya yang menjadi hambatan dalam memenuhi kebutuhan pelanggan secara efektif.

c. Opportunities (Peluang) merupakan situasi utama yang menguntungkan dalam lingkungan suatu perusahaan.

d. Threats (Ancaman) merupakan situasi utama yang tidak menguntungkan dalam lingkungan suatu perusahaan

Penyusunan alur pemikiran penelitian ini adalah melakukan analisis SWOT terkait pelayanan online store shopee. Analisis SWOT dlakukan dengan melihat faktor yang berada pada internal yaitu kekuatan dan kelemahan yang terdapat pada online store shopee sedangkan faktor eksternal terdiri dari peluang dan ancaman pada online store shopee. Setelah dilakukan pengolahan data, maka analisis SWOT akan menghasilkan gambaran mengenai keadaan yang akan dihadapi oleh online store shopee apakah ada pada kondisi kuat, lemah, berpeluang atau terancam. Selanjutnya dilakukan penentuan strategis sesuai dengan kondisi online store shopee. Berikut kerangka pemikiran pada penelitian ini:

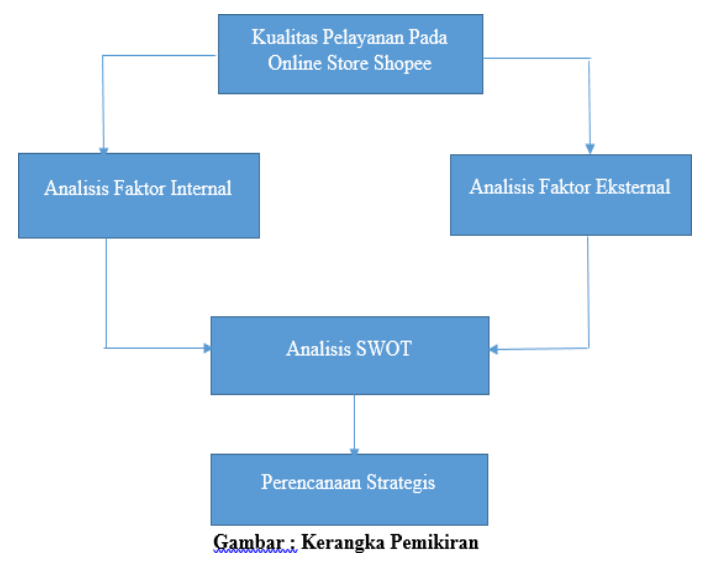




\section{METODOLOGI PENELITIAN}

\subsection{Jenis Penelitian}

Adapun objek penelitian ini adalah situs belanja yakni online store shopee. Penelitian ini menggunakan pendekatan deskriptif kualitatif. Penelitian deksriptif merupakan penelitian yang bertujuan untuk mendapatkan gambaran atau deskripsi tentang bagaimana kualitas pelayanan yang diberikan oleh online store shopee. Sedangkan analisis kualitatif menurut (Sugiyono, 2005) merupakan penelitian yang digunakan untuk meneliti pada kondisi objek alamiah, dimana peneliti merupakan instrument kunci. Sedangkan menurut (Moleong, 2002) analisis kualitatif sebagai prosedur peneltian yang menghasilkan data deskriptif yang dianalisa.

\subsection{Populasi Penelitian}

Dalam penelitian ini terdiri dari dua jenis populasi yang diteliti yaitu populasi internal dan populasi eksternal. Populasi internal yaitu populasi yang berasal dari admin seller. Admin seller berhubungan langsung dengan pihak konsumen. Admin seller yang diambil berjumlah 20 orang. Sedangkan populasi eksternal ditentukan berdasarkan jumlah mahasiswa sebanyak 250 orang yang diambil dari mahasiswa yang terdapat dikawasan kota palembang. Pengambilan sampel internal dan eksternal menggunakan teknik pengambilan sampel dalam penelitian ini adalah purposive accidental sampling yaitu pengambilan sampel melalui penentuan jumlah berdasarkan kriteria. Untuk kriteria populasi internal maka dipilih yaitu admin seller shopee dengan alasan yaitu admin seller shoppe adalah pihak yang berhubungan langsung dengan konsumen terkait dengan pelayanan konsumen terutama produk yang ditawarkan dan harga yang dipasarkan. Sedangkan untuk populasi eksternal adalah mahasiswa yang ada pada perguruan tinggi swasta yang berada di kota Palembang,

\subsection{Teknik Pengumpulan Data}

Proses pengumpulan data dilakukan dengan dua cara yaitu data primer dan data sekunder. Data primer adalah data yang diperoleh secara langsung melalui pihak internal dengan menggunakan media angket yang melibatkan admin seller, dimana admin seller merupakan pihak yang berhubungan langsung dengan konsumen dan melayani konsumen melalui fitur live chat yang terdapat pada online store shopee yang memungkinkan penjual dan pembeli yang akan berinteraksi mengenai produk yang dijual. Sedangkan pihak eksternal menggunakan penyebaran kuesioner yang melibatkan mahasiswa yang terdapat dikawasan kota Palembang, karna pengguna shopee kebanyakan kaum muda sehingga mahasiswa dijadikan sebagai sampel dalam keterlibatan pihak eksternal.

\subsection{Analisis Data}

Adapun tahapan pada pengolahan data yaitu melakukan uji kausalitas data. Uji kausalitas data terdiri dari validitas data dan reliabilitas data. Uji validitas merupakan tingkat keandalan dan kesahihan alat ukur yang digunakan. Instrumen dikatakan validjika menunjukan alat ukur yang validatau dapat digunakan untuk mengukur sesuatu yang seharusnya diukur. Adapun ketentuan yang digunakan sebagai dasar pengukuran untuk melakukan pengujian validitas data adalah jika Jika nilai t-tabel lebih besar daripada nilai t-statistik (t-hitung) maka data tersebut dinyatakan valid. Sedangkan uji reliabilitas data merupakan suatu pengujian yang bertujuan untuk melihat tingkat konsistensi dari jawaban yang diberikan oleh konsumen. Jika nilai Cronbach alpha diatas 0,60 maka data tersebut dikatakan reliabel. Setelah itu melakukan perhitungan bobot terkait faktor internal dan faktor eksternal. Adanya perhitungan bobot di 
dalam melakukan analisis SWOT memiliki tujuan yaitu untuk memberikan penilaian atau bobot mengenai seberapa besar pengaruh masing-masing pernyataan yang telah dibuat pada internal dan eksternal perusahaan terhadap kemajuan perusahaan. Adapun perhitungan bobot dengan ketentuan yaitu pemberian bobot mulai dari 1,0 (sangat penting) sampai 0,0 (tidak penting). Kemudian dari hasil perhitungan pengolahan data dapat dilakukan perhitungan bobot internal dan bobot eksternal. Rumus perhitungan bobot internal dan eksternal : Nilai pengolahan data kuesioner dibagi dengan total nilai pengolahan data kuesioner. Kemudian dari hasil perhitungan pengolahan data tersebut dilakukan perhitungan bobot internal dan eksternal dengan rumus yang telah ditentukan maka kemungkinan dapat memberikan dampak terhadap faktor strategis perusahaan.

Langkah selanjutnya adalah melakukan pemberian nilai rating. Pemberian nilai rating untuk variabel teridri atas indikator pada faktor internal yang meliputi kekuatan dan kelemahan dan faktor eksternal untuk variabel yang meliputi peluang dan ancaman. Penentuan pada rating faktor internal memliliki ketentuan indikato, dimana kekuatan diberi nilai 1 sampai dengan 4. Penentuan nilai 1 jika kemungkinan indikator tersebut dinilai kinerjanya mengalami penurunan dibandingkan dengan pesaing utama, untuk penentuan nilai 2 jika indikator tersebut kinerjanya sama dibandingkan dengan pesaing utama, nilai 3 atau 4 jika indikator tersebut lebih baik dibandingkan pesaing utama. Dengan demikian semakin tinggi nilainya memiliki arti yaitu kinerja indikator tersebut akan semakin baik jika dibandingkan pesaing utamanya. Sedangkan untuk indikator kelemahan diberi nilai 1 jika memiliki indikator yang banyak kelemahannya dari pesaing utamanya. Sedangkan diberi nilai 4 jika memiliki indikator yang semakin menurun jika dibandingkan pesaing utamanya rating.

Setelah pemberian pada nilai rating langkah berikutnya adalah analisis matrik faktor strategi internal. Matrik faktor strategi internal merupakan penyusunan matrik yang didalamnya terdiri atas kekuatan dan kelemahan perusahaan. Adarapun cara untuk menentukan matrik faktor strategi internal adalah dengan melakukan hasil perhitungan bobot kemudian dikalikan dengan rating dari kekuatan dan kelemahan tersebut dapat dijadikan sebagai sumbu $\mathrm{x}$ untuk menentukan posisi perusahaan,apakah dalam posisi menguat atau melemah. Jika hasil perhitungan positif maka perusahaan dalam posisi yang kuat, sedangkan jika hasil perhitungan negatif maka perusahaan dalam pisisi melemah. Maka perhitungan pada sumbu $\mathrm{x}$ adalah sebagai berikut yaitu sumbu $\mathrm{x}=$ jumlah bobot $\mathrm{x}$ rating kekuatan - jumlah bobot $\mathrm{x}$ rating kelemahan (Rangkuti,2005). Kemudian melakukan analisis matrik faktor strategi eksternal. Matrik Faktor Strategi Eksternal yang terdiri dari peluang dan ancaman perusahaan. Adapun hasil perhitungan bobot dikalikan dengan rating dari peluang dan ancaman tersebut dapat dijadikan sebagai sumbu y untuk menentukan bagaimana posisi perusahaan, apakah dalam posisi berpeluang atau terancam. Jika hasil perhitungan positif maka perusahaan dalam posisi berpeluang, dan jika perhitungan negatif maka perusahaan anda dalam posisi terancam. Adanya perhitungan pada sumbu $\mathrm{y}$ adalah sumbu $\mathrm{y}=$ jumlah bobot $\mathrm{x}$ rating peluang - jumlah bobot $\mathrm{x}$ rating ancaman (Rangkuti,2005). Dari sumbu x dan y tersebut selanjutnya dapat ditarik garis pada diagram SWOT dan mengetahui perusahaan dalam posisi kuandran 1, 2, 3 atau 4 serta dapat menentukan strategi mana yang cocok dalam rangka untuk meningkatkan kualitas pelayanan pada online store shopee.

\section{HASIL PENELITIAN}

\section{Uji Reliabilitas Data}

Uji reliabilitas dapat merupakan salah satu pengujian di dalam statsitik yang 
menunjukkan bahwa reliabilitas data menunjukkan tingkat konsistensi dari responden. Hasil pengujian reliabilitas data diperoleh dengan melihat nilai koefisien cronbach's alpha. Jika nilai koefisien cronbach's alpha menunjukkan nilai lebih dari $60 \%$ maka dapat dikatakan data tersebut reliabel sedangkan jika nilai koefisien Cronbach alpha dibawah $60 \%$ maka data menunjukkan bahwa data tersebut tidak reliabel. Berdasarkan hasil uji reliabilitas data didapatkan hasil yaitu koefisien Cronbach alpha sebesar 0.939 atau sebesar 93,90 \%. Hal ini menunjukkan bahwa tingkat konsistensi dari kuesioner yang diisioleh responden sebesar 93,9\% terdapat hasil bahwa konsistensi menjadi kuat.

\section{Uji Validitas Data}

Uji validitas data merupakan pengujian data yang menunjukkan seberapa valid atau layak pertanyaan yang telah disajikan kepada responden. Untuk mengukur tingkat validitas suatu data dapat dilakukan dengan membandingkan nilai t-tabel dengan t-statistik. Jika nilai ttabel lebih besar daripada nilai t-statistik (t-hitung) maka data tersebut dinyatakan valid sedangkan jika nilai t-tabel lebih kecil daripada nilai t-statistik (t-hitung) maka data tersebut dinyatakan tidak layak atau tidak valid.

\section{Tabel 1. Hasil Uji Validitas}

\begin{tabular}{|c|c|c|c|}
\hline \multicolumn{2}{|c|}{$\begin{array}{c}\text { Scale Mean if } \\
\text { Item Deleted }\end{array}$} & $\begin{array}{c}\text { Scale Variance } \\
\text { if Item Deleted }\end{array}$ & $\begin{array}{c}\text { Corrected Item- } \\
\text { Total Correlation }\end{array}$ \\
\hline P1 & 45.33 & 48.102 & .573 \\
\hline P2 & 45.37 & 47.551 & .568 \\
\hline P3 & 45.45 & 47.356 & .522 \\
\hline P4 & 46.46 & 42.755 & .821 \\
\hline P5 & 46.42 & 43.174 & .805 \\
\hline P6 & 46.53 & 43.573 & .762 \\
\hline P7 & 46.59 & 43.589 & .766 \\
\hline P8 & 45.54 & 45.178 & .703 \\
\hline P9 & 45.42 & 44.006 & .789 \\
\hline P10 & 45.53 & 44.994 & .694 \\
\hline P11 & 45.65 & 44.555 & .731 \\
\hline P12 & 45.50 & 44.697 & .731 \\
\hline P13 & 45.64 & 44.039 & .752 \\
\hline
\end{tabular}

Sumber : Hasil Penelitian (Data Diolah)

Berdasarkan hasil pengujian validitas data menunjukkan hasil pernyataan yang disajikan kepada responden valid atau layak. Hal ini dapat dilihat dari jumlah kuesioner sebanyak 270 responden sebesar t tabel sebesar 0,05 lebih besar dari t-hitung.

\section{Analisis SWOT}

Analisis SWOT adalah identifikasi berbagai faktor internal dan eksternal secara sistematis untuk menentukan kualitas pelayanan pada online shop pada shopee. Analisis ini 
didasarkan pada pada logika didalam memaksimalkan faktor internal berupa kekuatan dan peluang dan juga meminimalkan faktor eksternal yaitu kelemahan dan ancaman. Berikut ini adalah beberapa rincian faktor internal dan faktor eksternal dalam analisis SWOT pada online shop pada shopee.

1. Faktor internal yang berasal dari lingkungan internal online shop pada Shopee. Dimana lingkungan internal pada analisis SWOT shopee diambil berdsarkan admin shopee. Admin shopee berperan memberikan pelayanan kepada customer terkait dengan barang dagangan atau produk yang dijual. Kekuatan dan kelemahan pada online shop shopee adalah sebagai berikut :
a. Kekuatan

1. Hampir setiap barang yang dibutuhkan tersedia

2. Modal yang dibutuhkan relatif kecil

3. Menggunakan jasa pengiriman yang professional

b. Kelemahan

1. Kesulitan berkomunikasi dengan admin seller

2. Deskripsi barang yang disajikan belum lengkap

3. Walaupun menggunakan jasa pengiriman yang professional masih sering terdapat kesalahan dalam proses pengiriman barang konsumen

4. Mahalnya biaya ongkir

2 Faktor eksternal yang berasal dari lingkungan eksternal, dimana lingkungan eksternal yaitu dari sisi pengguna online shop pada shopee yakni mahasiswa yang berada dikawasan kota Palembang. Berikut peluang dan ancaman pada online shop shopee sebagai berikut :

a. Peluang

1. Bisa melakukan ekspansi atau perluasan usaha

2. Kesempatan besar untuk meningkatkan income karena maraknya orang yang berbelanja secara online

3. Banyaknya konsumen yang berlangganan secara online karena banyaknya produk yang memiliki kualitas bagus

b. Kelemahan

1. Adanya mindset bahwa berbelanja secara online sangatlah beresiko

2. Banyaknya kasus penipuan yang terjadi

3. Lingkungan usaha yang berubah-ubah

3. Faktor internal yang berasal dari lingkungan internal online shop pada Shopee. Dimana lingkungan internal pada analisis SWOT shopee diambil berdsarkan admin shopee. Admin shopee berperan memberikan pelayanan kepada customer terkait dengan barang dagangan atau produk yang dijual. Kekuatan dan kelemahan pada online shop shopee adalah sebagai berikut :

a. Kekuatan

1. Hampir setiap barang yang dibutuhkan tersedia

2. Modal yang dibutuhkan relatif kecil

3. Menggunakan jasa pengiriman yang professional

b. Kelemahan

1. Kesulitan berkomunikasi dengan admin seller

2. Deskripsi barang yang disajikan belum lengkap

3. Walaupun menggunakan jasa pengiriman yang professional masih sering 
terdapat kesalahan dalam proses pengiriman barang konsumen

4. Mahalnya biaya ongkir

4. Faktor eksternal yang berasal dari lingkungan eksternal, dimana lingkungan eksternal yaitu dari sisi pengguna online shop pada shopee yakni mahasiswa yang berada dikawasan kota Palembang. Berikut peluang dan ancaman pada online shop shopee sebagai berikut :

a. Peluang

1. Bisa melakukan ekspansi atau perluasan usaha

2. Kesempatan besar untuk meningkatkan income karena maraknya orang yang berbelanja secara online

3. Banyaknya konsumen yang berlangganan secara online karena banyaknya produk yang memiliki kualitas bagus

b. Kelemahan

1. Adanya mindset bahwa berbelanja secara online sangatlah beresiko

2. Banyaknya kasus penipuan yang terjadi

3. Lingkungan usaha yang berubah-ubah

5. Faktor internal yang berasal dari lingkungan internal online shop pada Shopee. Dimana lingkungan internal pada analisis SWOT shopee diambil berdsarkan admin shopee. Admin shopee berperan memberikan pelayanan kepada customer terkait dengan barang dagangan atau produk yang dijual. Kekuatan dan kelemahan pada online shop shopee adalah sebagai berikut :

a. Kekuatan

1. Hampir setiap barang yang dibutuhkan tersedia

2. Modal yang dibutuhkan relatif kecil

3. Menggunakan jasa pengiriman yang professional

b. Kelemahan

1. Kesulitan berkomunikasi dengan admin seller

2. Deskripsi barang yang disajikan belum lengkap

3. Walaupun menggunakan jasa pengiriman yang professional masih sering terdapat kesalahan dalam proses pengiriman barang konsumen

4. Mahalnya biaya ongkir

6. Faktor eksternal yang berasal dari lingkungan eksternal, dimana lingkungan eksternal yaitu dari sisi pengguna online shop pada shopee yakni mahasiswa yang berada dikawasan kota Palembang. Berikut peluang dan ancaman pada online shop shopee sebagai berikut :

a. Peluang

1. Bisa melakukan ekspansi atau perluasan usaha

2. Kesempatan besar untuk meningkatkan income karena maraknya orang yang berbelanja secara online

3. Banyaknya konsumen yang berlangganan secara online karena banyaknya produk yang memiliki kualitas bagus

b. Kelemahan

1. Adanya mindset bahwa berbelanja secara online sangatlah beresiko

2. Banyaknya kasus penipuan yang terjadi

3. Lingkungan usaha yang berubah-ubah 


\section{Matrik Faktor Strategi Internal}

Matriks faktor internal merupakan matrik yang menunjukkan kekuatan dan kelemahan yang terdapat didalam internal perusahaan. Kekuatan merupakan seluruh sumber daya yang potensal dimiliki oleh perusahaan yang menunjukkan adanya pemanfaatan hasil sumber daya yang dapat dioptimalkan oleh perusahaan.

Analisis Strategi SO menggunakan analisis yang berkaitan dengan faktor internal yakni adanya faktor kekuatan yang digunakan untuk memanfaatkan peluang atau kesempatan didalam melakukan peningkatan kualitas pelayanan yang diberikan oleh online store shopee. Strategi SO yang dijalankan oleh perusahaan yaitu dengan melakukan peningkatan kualitas pelayanan. Berikut hasil analisis matrik IFAS ditunjukkan pada tabel dibawah ini :

Tabel 2. Hasil Analisis Matrik IFAS

\begin{tabular}{|c|l|c|c|c|}
\hline Kode & \multicolumn{1}{|c|}{ Keterangan } & Rating & Bobot & Score \\
\hline S1 & $\begin{array}{l}\text { Hampir semua barang yang } \\
\text { dibutuhkan tersedia }\end{array}$ & 4 & 0.17 & 0.68 \\
\hline S2 & $\begin{array}{l}\text { Modal yang dibutuhkan relatif } \\
\text { kecil }\end{array}$ & 4 & 0.17 & 0.68 \\
\hline S3 & $\begin{array}{l}\text { Menggunakan jasa pengiriman } \\
\text { yang professional }\end{array}$ & 4 & 0.17 & 0.68 \\
\hline \multicolumn{2}{|c|}{ Total Perhitungan Bobot Kekuatan } \\
\hline Kode & \multicolumn{1}{|c|}{ Rating } & Bobot & Score \\
\hline W1 & $\begin{array}{l}\text { Kesulitan berkomunikasi dengan } \\
\text { admin seller }\end{array}$ & 3 & 0.13 & 0.39 \\
\hline W2 & $\begin{array}{l}\text { Deskripsi barang yang disajikan } \\
\text { belum lengkap }\end{array}$ & 3 & 0.13 & 0.39 \\
\hline & $\begin{array}{l}\text { Walaupun menggunakan jasa } \\
\text { pengiriman yang professional masih } \\
\text { sering terdapat kesalahan }\end{array}$ & 3 & 0,12 & 0.36 \\
\hline W3 & 3 & 0,12 & 0.36 \\
\hline W4 & Mahalnya biaya ongkir & $\mathbf{1 . 5 0}$ \\
\hline \multicolumn{2}{|c|}{ Total Perhitungan Matrik IFAS } \\
\hline
\end{tabular}

Sumber : Hasil Penelitian (Data Diolah)

Berdasarkan hasil matrik IFAS tabel diatas maka dapat ditentukan sumbu x yang berfungsi untuk menentukan posisi perusahaan berada pada posisi kuat atau lemah. Didalam mencari sumbu $\mathrm{x}$ dilakukan dengan cara yakni sumbu $\mathrm{x}=$ jumlah bobot $\mathrm{x}$ rating kekuatan jumlah bobot $x$ rating kelemahan. Berdasarkan rumus tersebut maka dapat ditentukan nilai pada sumbu $\mathrm{x}$ yaitu total perhitungan bobot kekuatan sebesar 2,04 dikurangi dengan total perhitungan bobot kelemahan yaitu 1.50 sehingga sumbu x adalah sebesar 0.54. Sehingga dari hasil perhitungan tersebut maka dapat dilihat bahwa posisi kualitas pelayanan online store shopee dalam posisi yang kuat.

\section{Matrik Faktor Strategi Eksternal}

Matrik faktor strategi eksternal berguna untuk merumuskan faktor-faktor strategis eksternal pelayanan online store shopee dalam kerangka peluang (Opportunities) and kesempatan (Threats) dengan melihat berbagai kemungkinan adanya peluang dan ancaman 
yang akan dihadapi online store shopee. Berikut hasil analisis matrik EFAS ditunjukkan pada tabel dibawah ini :

Tabel 3. Hasil Analisis Matrik EFAS

\begin{tabular}{|c|l|c|c|c|}
\hline Kode & \multicolumn{1}{|c|}{ Keterangan } & Rating & Bobot & Score \\
\hline O1 & Bisa melakukan ekspansi secara luas & 4 & 0.17 & 0.68 \\
\hline O2 & $\begin{array}{l}\text { Semakin maraknya konsumen yang berbelanja } \\
\text { menggunakan media online membuat kesempatan } \\
\text { yang besar untuk meningkatkan income }\end{array}$ & 4 & 0.17 & 0.68 \\
\hline O3 & $\begin{array}{l}\text { Barang yang bagus dan murah membuat konsumen } \\
\text { banyak yang berlangganan }\end{array}$ & 4 & 0.17 & 0.68 \\
\hline \multicolumn{2}{|c|}{ Total Perhitungan Bobot Peluang } & & $\mathbf{2 . 0 4}$ \\
\hline Kode & \multicolumn{1}{|c|}{ Keterangan } & Rating & Bobot & Score \\
\hline T1 & $\begin{array}{l}\text { Adanya Mind Set bahwa berbelanja secara online } \\
\text { sangatlah berisko }\end{array}$ & 3 & 0.16 & 0.48 \\
\hline T2 & Banyaknya penipuan yang terjadi & 4 & 0.17 & 0.68 \\
\hline T3 & Lingkungan pasar yang berubah-ubah & 3 & 0.17 & 0.51 \\
\hline & \multicolumn{2}{|c|}{ Total Perhitungan Bobot Ancaman } & 1.67 \\
\hline
\end{tabular}

Sumber : Hasil Penelitian (Data Diolah)

Dari matrik EFAS diatas dapat ditentukan sumbu y untuk mengetahui posisi perusahaan berada pada posisi berpeluang atau terancam. Untuk mencari sumbu y dilakukan dengan cara yaitu Sumbu y = jumlah bobot $\mathrm{x}$ rating peluang - jumlah bobot $\mathrm{x}$ rating ancaman. Berdasarkan rumus tersebut maka dapat ditentukan nilai pada sumbu $\mathrm{x}$ yaitu total perhitungan bobot peluang sebesar 2,04 dikurangi dengan total perhitungan bobot kelemahan yaitu 1.67 sehingga sumbu $\mathrm{x}$ adalah sebesar 0.37. Sehingga dari hasil perhitungan tersebut maka dapat dilihat bahwa posisi kualitas pelayanan online store shopee dalam posisi yang berpeluang.

\section{Pembahasan}

Diagram analisis SWOT adalah suatu alat yang digunakan untuk mengetahui bagaimana posisi koordinat dan kuadran mana posisi strategi perusahaan. Hasil pengolahan matrik faktor strategi internal dan matrik faktor strategi eksternal dapat ditentukan posisi pelayanan Online Store Shopee. Dalam matrik faktor strategi internal diperoleh hasil sumbu x yaitu berada pada koordinat 0.54 , sedangkan dalam matrik faktor strategi eksternal sumbu y berada pada koordinat 0.37. Dari kedua koordinat tersebut dapat ditentukan posisi perusahaan berada dalam koordinat 1,2,3 atau 4 yang masing-masing kuadran mendukung setiap strategi. Berikut adalah gambar yang terkait diagram SWOT adalah sebagai berikut: 


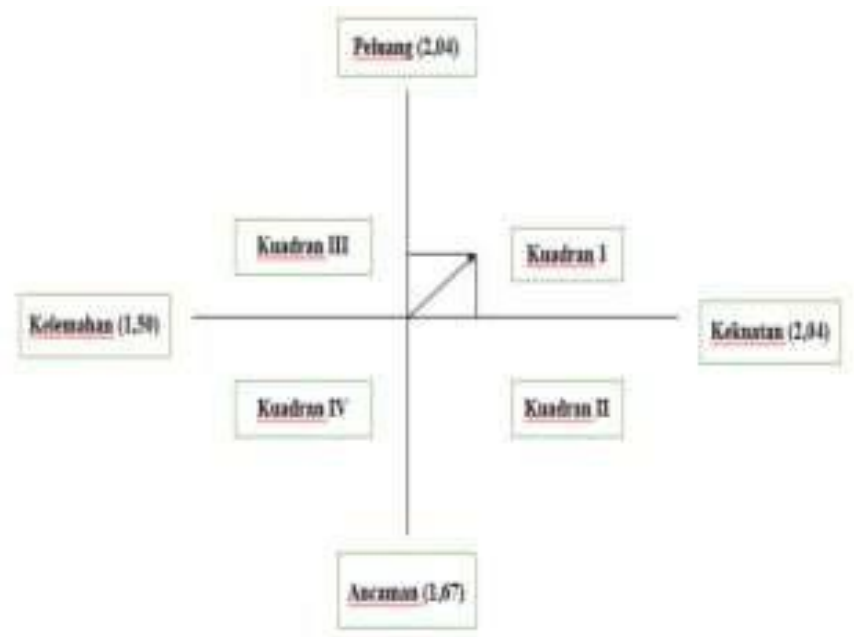

\section{Gambar 2. Diagram Analisis SWOT pada Online Store Shopee}

Berdasarkan pada gambar tesebut, kuadran analisis SWOT diatas dapat dilihat bahwa posisi pelayanan kualitas pelayanan online store shopee berada dalam kuadran satu yang artinya mendukung strategi agresif atau pertumbuhan karena sumbu y berada pada posisi peluang dengan nilai 0.37 dan sumbu $x$ berada pada posisi kuat dengan nilai 0.54. Berdasarkan tabel IFAS terdapat kelemahan yakni kesulitan berkomunikasi dengan admin seller mempunyai bobot sebesar 0.39 dan adanya deskripsi barang yang disajikan belum lengkap pada online store shopee mempunyai bobot 0.39 dapat diimplementasikan dalam strategi konsentrasi. Strategi konsentrasi dapat dilakukan dengan memaksimalkan komunikasi terutama respon admin seller kepada konsumen. Kemudian untuk deskripsi barang yang tidak lengkap maka pihak shopee sebaiknya melengkapi permintaan konsumen terkait dengan produk yang ditawarkan dalam rangka meningkatkan pelayanan online store shopee. Oleh karena itu online store shopee perlu menyusun strategi dalam rangka peningkatan kualitas pelayanan dalam upaya mencapai laba setiap tahunnya.

Penyusunan matrik SWOT berdasarkan pada matrik faktor strategi internal dan matrik faktor strategi eksternal kemudian menciptakan strategi-strategi baru berdasarkan faktor-faktor tersebut. Berikut matrik SWOT terkait dengan pelayanan online store shopee adalah sebagai berikut :

Tabel 4. Hasil Analisis Matrik SWOT

\begin{tabular}{|c|c|c|}
\hline & Strength(S) & Weakness $(\mathbf{W})$ \\
\hline & $\begin{array}{l}\text { 1. Hampir semua barang yang } \\
\text { dibutuhkan tersedia }\end{array}$ & $\begin{array}{l}\text { 1. Kesulitan berkomunikasi } \\
\text { dengan admin seller }\end{array}$ \\
\hline & $\begin{array}{l}\text { 2. } \begin{array}{l}\text { Modal yang dubutkan } \\
\text { relative kecil }\end{array} \\
\end{array}$ & $\begin{array}{l}\text { 2. Deskripsi barang yang } \\
\text { disajikan belum lengkap }\end{array}$ \\
\hline EFAS & $\begin{array}{l}\text { 3. Menggunakan jasa } \\
\text { pengiriman yang profesional }\end{array}$ & $\begin{array}{l}\text { 3. Walaupun menggunakan jasa } \\
\text { pengiriman professional masih } \\
\text { sering terjadi kesalahan }\end{array}$ \\
\hline & & 4. Mahalnya biaya ongkir \\
\hline Opportunites (O) & Strategi SO & Strategi WO \\
\hline $\begin{array}{l}\text { 1. Bisa melakukan ekspansi } \\
\text { secara luas }\end{array}$ & 1. Memperluas Jaringan pasar & $\begin{array}{l}\text { 1. Melengkapi barang yang } \\
\text { dibutuhkan oleh konsumen } \\
\text { pada fitur deskripsi barang }\end{array}$ \\
\hline $\begin{array}{l}\text { 2. Semakin maraknya } \\
\text { konsumen yang melakukan }\end{array}$ & $\begin{array}{l}\text { 2. Membuat varian produk yang } \\
\text { mengikuti selera konsumen }\end{array}$ & $\begin{array}{l}\text { 2. Meningkatkan interaktif } \\
\text { dalam bentuk komunikasi }\end{array}$ \\
\hline
\end{tabular}




\begin{tabular}{|c|c|c|}
\hline $\begin{array}{l}\text { berbelanja online membuat } \\
\text { kesempatan yang besar } \\
\text { untuk meningkatkan income }\end{array}$ & & $\begin{array}{l}\text { terutama peran admin seller } \\
\text { sebagai pihak yang melayani } \\
\text { konsumen }\end{array}$ \\
\hline $\begin{array}{l}\text { 3. Barang yang bagus dan } \\
\text { murah membuat konsumen } \\
\text { berlangganan }\end{array}$ & & $\begin{array}{l}\text { 3. Menggunakan jasa pengiriman } \\
\text { yang professional dalam } \\
\text { bentuk jalinan kerjasama } \\
\text { untuk memenuhi kebutuhan } \\
\text { pelanggan sehingga tepat } \\
\text { sasaran }\end{array}$ \\
\hline Threats (T) & Strategi ST & Strategi WT \\
\hline $\begin{array}{l}\text { 1. Adanya mindset bahwa } \\
\text { belanja online sangat } \\
\text { beresiko }\end{array}$ & $\begin{array}{l}\text { 1. Meningkatkan kualitas daya } \\
\text { saing }\end{array}$ & $\begin{array}{l}\text { 1. Peningkatan mutu Sumber } \\
\text { Daya Manusia }\end{array}$ \\
\hline $\begin{array}{l}\text { 2. Banyaknya penipuan yang } \\
\text { terjadi }\end{array}$ & $\begin{array}{ll}\text { 2. } & \text { Meningkatkan pada } \\
\text { pemusatan jasa dan kepuasan } \\
\text { pelanggan }\end{array}$ & $\begin{array}{l}\text { 2. Peningkatan layanan } \\
\text { pemesanan barang yang tepat } \\
\text { waktu }\end{array}$ \\
\hline \begin{tabular}{|l|} 
3. Lingkungan pasar yang \\
berubah ubah
\end{tabular} & & $\begin{array}{l}\text { 3. Meningkatkan efektivitas } \\
\text { iklan di sosial media }\end{array}$ \\
\hline
\end{tabular}

Sumber : Hasil Penelitian (Data Diolah)

\section{KESIMPULAN}

Kesimpulan yang dapat diambil pada penelitian ini adalah kualitas pelayanan online store shopee berada masih pada posisi yang kuat. Posisi yang kuat ini dapat dilihat dari bagaimana online store shopee memanfaatkan kekuatan dan peluang yang dimiliki dan terus memperbaiki kelemahan dan mampu bersaing dengan online store lainnya.

\section{SARAN}

Saran-saran yang dapat diambil berdasarkan hasil penelitian ini adalah bagi peneliti selanjutnya yang mempunyai penelitian yang sejenis untuk menambah variabel-variabel yang lebih mewakili agar dapat dijadikan sebagai bahan pertimbangan didalam melakukan penelitian.

\section{DAFTAR PUSTAKA}

A Muwafik Saleh. 2010.“Manajemen Pelayanan“. Pustaka Pelajar. Jakarta.

Kotler, Philip. 2002. Manajemen Pemasaran di Indonesia : Analisis, Perencanaan, Implementasi dan Pengendalian. Salemba Empat. Jakarta.

Moleong, J. Lexy. 2010. Metodologi Penelitian Kualitatif. Bandung: PT Remaja Rosdakarya.

Mujiyana, Ingge Elissa. 2013. Analisis faktor-faktor yang mempengaruhi keputusan pembelian via internet pada toko online. Jurnal Teknologi Informasi. Vol VIII. No 3.

Pearce, John A. dan Robinson, Richard B. 2013. Manajemen Strategis: Formulasi, Implementasi, dan Pengendalian.Jakarta: Salemba Empat.

Rangkuti, Freddy. (2009). Strategi Promosi yang Kreatif dan Analisis Kasus Integrated Marketing Communication. Jakarta : PT. Gramedia Pustaka Utama.

Sari, Chacha Andira. 2015. Perilaku Berbelanja Online Di Kalangan Mahasiswi Antropologi Di Universitas Airlangga, Jurnal Antro Unairdot Net: Vol. 4 No. 2.

Tjiptono, Fandy. 2001. Strategi Pemasaran. Edisi Pertama. Andi Ofset.Yogyakarta.

Tjiptono, Fandy. 2007. Strategi Pemasaran. Edisi Pertama. Andi Ofset.Yogyakarta.

Sugiyono. 2005. Memahami Penelitian Kualitatif. Bandung: CV. Alfabeta. 